This item was submitted to Loughborough's Research Repository by the author.

Items in Figshare are protected by copyright, with all rights reserved, unless otherwise indicated.

\title{
Beyond the street: the institutional life of rap
}

PLEASE CITE THE PUBLISHED VERSION

https://doi.org/10.1017/S0261143020000355

PUBLISHER

Cambridge University Press

VERSION

AM (Accepted Manuscript)

PUBLISHER STATEMENT

This article has been published in a revised form in Popular Music https://doi.org/10.1017/S0261143020000355. This version is published under a Creative Commons CC-BYNC-ND. No commercial re-distribution or re-use allowed. Derivative works cannot be distributed. (C) The Authors.

\section{LICENCE}

CC BY-NC-ND 4.0

\section{REPOSITORY RECORD}

Bramwell, Richard, and James Butterworth. 2020. "Beyond the Street: The Institutional Life of Rap". Loughborough University. https://hdl.handle.net/2134/37182. 


\title{
Beyond the street: the institutional life of rap
}

\begin{abstract}
This article draws on ethnographic fieldwork conducted over the course of one year in London and Bristol to examine the performance of rap in English youth centres. Youth centres play a significant role in supporting and shaping rap culture. However, historically dominant narratives within hip-hop studies and hip-hop culture depict rap as a vernacular cultural form that emerges from 'the street', and which derives its authenticity through its relation to 'the street'. We seek to move beyond such discourses and towards a recognition of the institutional processes, structures and networks that shape and sustain rap culture. Our focus on the institutional life of rap leads to an analysis of the various possibilities, limitations, and tensions that arise in the coming together of public funding, and social policy priorities, local organisations, and black vernacular culture.
\end{abstract}

\section{Introduction}

Rap is the most popular poetic form in the world today. With artists such as Stormzy, Dizzee Rascal, Roll Deep, Wretch 32 and Tinie Tempah reaching the top of the UK charts, rap music has become a prominent part of mainstream British life. Beyond the charts, UK hip-hop and grime are also politically significant subcultures, through which working-class youths use rap to represent their conditions of urban dwelling (Bramwell 2015). Historically dominant narratives depict rap as a cultural form that emerges from 'the street' (Chang 2007) and, even where it travels beyond 'the street', derives its legitimacy, authenticity and power through its relation to 'the street' (Forman 2000; Rose 1994). Although some scholars of hip-hop refer to institutions, such as youth organisations, (Dimitriadis, Clay), schools (Turner 2017), nightclubs and record shops (Bennet 1999), and the wider record industry (Negus 1999), 
there is relatively little critical analysis of the role that these institutions play in the reproduction and dissemination of rap culture within the field. For the greater part hip-hop studies conceives of 'the street' as the primary frame through which rap should be understood (Keyes 2004, Rose 1994).

Alongside the prominent position of 'the street', there is a substantial concern in hiphop studies with the role of rap music in the construction of identity. Scholars approaching this cultural form from the perspective of music and literary studies tend to foreground the construction of identity through the stylistic strategies and dominant themes employed by artists in rap 'texts' (Krims 2000; Kajikawa 2015). By contrast, scholars approaching hip-hop from sociological and cultural studies perspectives, often highlight how it is used by young people to construct their social identities (Bennett 1999; Dimitriadis 2009; Rose 1994). Although these accounts may refer to the context in which these identities are expressed (Dimitriadis 2009) or how the response of audiences may restrict or enable an artist's success (Kajikawa 2015), the organisational contexts of performance and reception in shaping rap culture and the identities produced through it, is largely unexamined in hip-hop scholarship.

It is our contention that the emphasis on 'the street' and identity, in hip-hop culture and scholarship, has led to a lack of critical inquiry about the institutional life of rap. It may seem obvious, but it is rarely explicitly acknowledged that rap songs, music, and recordings are produced and performed in a variety of organisational contexts. We suggest that this fact alone necessitates much greater scholarly attention to the role that institutions play in the shaping of rap cultures and, in turn, the impact that rap has on these institutions. Moreover, we argue that the aesthetics, meanings and effects of rap are not simply transported to, or appropriated by, institutions; rather, they are fundamentally constituted in, through and by them. 


\section{Neo-institutionalism and the invisibility of institutions in hip-hop studies}

Urpelainen (2011) offers a definition of an institution as 'a set of shared individual expectations about self-enforcing collective behaviours in a social situation.' Specific examples of institutions 'may include markets, firms, schools, hospitals, football clubs and so on' (Banks 2007) or the 'music and culture industries' (Forman 2002). Although in this article, our focus is on formal organisations, funded by local or national government, we conceive of institutions more broadly. We understand institutions as regimes of norms and practices, and that these practices organise both material and symbolic resources. Our argument about the central importance of institutions in the formation of rap cultures draws upon debates within sociological neo-institutionalism (Alasuutari 2015; Regev 2007). Hall and Taylor (1996) identify three distinct types of 'new institutionalism': historical institutionalism, rational choice institutionalism, and sociological institutionalism. These approaches developed largely independently of one another and offer distinct approaches to social and political problems. For Hall and Taylor 'sociological institutionalists tend to define institutions much more broadly than political scientists do to include, not just formal rules, procedures or norms, but the symbol systems, cognitive scripts, and moral templates that provide the "frames of meaning" guiding human action.' With this borne in mind both hiphop and grime should be understood as institutionalised 'fields of cultural production' (Regev 2007). The dominant role of the 'street', in discussions within and about hip-hop, can therefore be seen as one example of the enforcement of collective behaviours within that field. Although Forman (2002) generally reserves his use of the term to his analysis of the music and culture industries, his discussion of hip-hop's textual and discursive 'spatial modalities' comes close to recognising the institutional character of hip-hop culture itself. However, our primary intention here is not develop a critique of rap cultures as institutions, 
but rather to examine how these regimes of norms are shaped by institutions and how they in turn influence practice within those institutions.

As this paper will focus on the production of rap culture it is necessary to explain our use of the terms rap, hip-hop and grime, particularly as rap and hip-hop are often conflated in public discourse. We use the term rap to refer to the practice of lyrical performance, by an MC or rapper, often over an instrumental background (Kajikawa 2015). Our interest in hiphop and grime arises as rap is an important component in both genres of music and the subcultures associated with them. We therefore use the term 'rap cultures' to bridge across generic distinctions and to refer to cultural fields in which rap plays a significant role.

Rap is regularly practiced in institutional settings. This is evident from the plethora of articles in the areas of rap therapy and hip-hop education, which discuss the use of hip-hop in the USA as therapeutic (Elligan 2000; Tillie Allen 2005; Gonzales and Grant Hayes 2009; Olson-McBride and Page 2012) and pedagogical tools (Emdin 2010; Cermak 2012; Kuttner 2015; Hallman 2009; Morrel and Duncan-Andrade 2002; Stephens et al 1998). These articles tend toward advocating for the power of hip-hop to generate knowledge, well-being and prosocial behaviour among African-American and/or 'hard to reach' groups. In such work, the institutional context is assumed rather than critically engaged with, due to the orientation towards practitioners that are already operating within specific institutional contexts (e.g. health, educational or penal institutions). As a result, one gleans little about the wider institutional structures, practices and politics surrounding hip-hop performance, or the interaction between mainstream hip-hop culture and the culture within these institutions.

Within the field of hip-hop studies several scholars have attended to the practice, performance and dissemination of hip-hop culture within a variety of institutional contexts. Keith Negus, for example, examines how the organisational practices in the music industry shape rap music production. Negus (1999) describes how uncritically received notions of 'the 
street' shape the way that record companies produce knowledge about their markets and act upon that knowledge. Murray Forman's examination of spatial practices in hip-hop and rap culture charts the development of rap in the Bronx, through its incorporation in the culture industries and its subsequent international dissemination. Building on Negus's work, Forman's analysis highlights the organisational processes through which rap has been adapted by private commercial enterprises. By contrast Derek Pardue provides an ethnographic evaluation of the use of hip-hop within public organisations. Pardue's (2004) analysis of the pedagogical use of hip-hop in youth correctional facilities in the Brazilian city of São Paulo explores the tensions in the state's facilitation of a cultural practice that is often associated with 'social critique'. Geoff Baker $(2005 ; 2011)$ observes a more striking case of state involvement in the production of rap culture, documenting explicit state attempts to support, control and nationalise Cuban rap through a range of festivals and organisations. Baker (2005) contends that the success of the state's engagement with rap relies on the convergence of rap as a form of protest music and Cuba understood as a 'protest state'. Baker's argument is founded to a large extent on a form of Cuban exceptionalism, but our research demonstrates that state and civic institutions can play an incredibly important role in promoting and shaping rap culture in Western capitalist democracies. Writing about hip-hop in Germany since the 1980s, Michael Hoyler and Christoph Mager (2005) argue that it was 'the built environment of [state-sponsored] community centres and youth clubs that ... played the most significant role in the creation of the first generation 'Old School' hip-hop in [East and West] Germany'.

In the UK, Patrick Turner (2017) has examined hip-hop as a form of edutainment in a range of settings, including schools, youth centres, and public theatres, and Joy White examines the entrepreneurial practices of grime artists. White (2017) locates grime MCs and DJs within the 'social field' of the urban music economy, understood as a 'complex fabric 
containing a multiplicity of roles and practitioners operating within and across the sector as artists and entrepreneurs.' Although her focus is on the business activities of artistentrepreneurs, White's analysis highlights how the collaborative activities of individuals and groups contribute to the development of this field. Our study builds on this work, and we argue that the concept of the institution enables analysis of how the structure of this cultural field is produced through the links between private entrepreneurial activity, government departments and other public bodies, and organisations that may draw upon a combination of public funding, voluntary work, and commercial activity.

This article forms part of a wider research project that examines rap culture in a variety of institutions in England, which are wholly or partially state-funded. ${ }^{1}$ Our focus on institutions receiving public funding stems from an interest in how the state supports, suppresses and shapes rap cultures. Our wider project also engages with the role of local and national government in shaping young people's identities through rap. We have sought to examine how institutions differ in their approaches to and engagement with rap. In their study of youth participants in a Boys and Girls Club program, in the United States, AndersonButcher, Cash, Saltzburg, Midle, and Pace (2004) argue that 'youth development organizations are key institutions that contribute to healthy outcomes for youths'. There is a substantial body of work examining the role of rap in shaping young people's identities in youth organisations. However, in this article we to explore questions around how rap is valued within institutions; how these organisations sustain, shape and restrict rap scenes; and how and to what ends institutions seek to use rap. By approaching rap through institutions,

\footnotetext{
${ }^{1}$ As part of our argument about the importance of institutions we also wish to acknowledge the significance of privately funded organisations such as record companies, record shops, night clubs, and radio stations to the development and reproduction of rap cultures.
} 
we analyse what is at stake when the relationship between the state and young people is constructed through rap culture. In this paper we explore these issues through an examination of rap culture in youth centres in two English cities: London and Bristol.

\section{Forest Gate Youth Zone, Newham, London}

Grime is generally accepted to have developed in London. White (2017) identifies its origins in the boroughs of Tower Hamlets and Newham. In contrast Bramwell (2015) highlights how youths in south London also contributed to the formation of this genre. Regardless of the geographical origins of this rap culture, grime emerged from the garage scene, drawing on the resources of the city's soundsystem culture. Youth centres played an important role in the artistic development of a number of widely recognised figures within London's nascent grime scene. MCs came together in these social institutions to practice their craft, focusing on the 'tightness' of their lyrics and the delivery of their 'bars' (Bramwell 2015). In 2015-16 we conducted fieldwork in three out of four youth centres operated by Newham Council (Forest Gate, Little Ilford and Shipman). Forest Gate youth centre had once played an important role within London's grime scene. Carl, a youth worker at the Forest Gate Youth Zone who had grown up in the area, asserted:

Forest Gate Youth Centre as far as Newham is concerned - Forest Gate and Little Ilford ... are the most well-known. Forest Gate used to have events here all the time. A lot of the semi-famous or famous quote unquote 'grime' artists have visited here or been here to polish their skills...' (Carl, Youth Worker).

Although he had not regularly attended the youth centre as a teenager, Carl recalled seeing a number of artists perform at the institution, during his youth:

Crazy [Titch] used to come here sometimes, ... D Double, Footsie, Monkey who doesn't MC anymore he's come here. ... I wasn't really a youth club person, most 
of my activities was not really youth centre based to be fair. But you'd go somewhere, you know if someone said 'this is happening' you'd go somewhere so if they had like a - something was happening at Forest Gate. (Carl, Youth Worker) Newham Council provided space, resources and staff through Forest Gate Youth Zone. Through the provision of this youth service the local authority made a significant contribution to the vibrant rap culture in East London, within which grime formed.

Today there is no regular provision of music production sessions or studio space at the centre, and no facilitation of rap performances through which another generation of young people might develop their own creative practice. Following the implementation of austerity policies (initiated by the Conservative and Liberal Democrat coalition and continued under the Conservative government) the London Borough of Newham reduced its youth service budget by $75 \%$. As a result, Forest Gate Youth Zone experienced a dramatic reduction in the number of days that it opened, the number of sessions run during the week, and the staff through which to provide a service to young people in the neighbourhood.

The Children and Young People's Service Manager, described the impact that budget cuts had on her ability to provide services to young people, and the strategy that she adopted in order to attempt to mitigate the impact of these cuts.

I manage the internally-commissioned side of it [the council's youth service provision], which is the four centres [Forest Gate, Little Ilford, Shipman, and Beckton Youth Zones]. And our budget pays for four sessions of youth work: two after school and two evening each week in the four centres. That's it - that's all my budget will allow for. Clearly, that's not enough, because young people were used to ten sessions a week; ten or eleven sessions. So what I did is I just went out and I just formulated lots and lots of partnerships. So I see that as my role; I make things my role. So my role is to run the four sessions, so on top of that I've developed 
numerous partnerships so that when we're not using the space, other people come in and they deliver a service to young people, so that that expands the offer, it enriches the offer. (Service Manager)

In addition to the impact that the dramatic cuts to local government budgets had on Newham's youth services, the ability of youth centres in the borough to support the local rap culture was affected by the departure of key individuals. Between 2010 and 2016 there was a significant reduction in the number of full-time staff in Newham's Children and Young People's Service: 'five, six years ago we had fifty full-time workers, and so now we've got four' (Service Manager). The Centre Manager at Forest Gate Youth Zone, described the impact that the departure of one of her staff members had on the centre:

I had one of my workers, when I first became a manager in here, Steven, he doesn't work here with us anymore, he used to do music with young people. And you know, he would start training the ones who was interested into singing or rapping. ... We used to have freestyle sessions, when I had my old staff. Unfortunately, we don't have it anymore.... My first year here was one of my best years: I think losing that staff who has the music background, a youth worker, it had affected me really, really, bad, because he was like - my other staff unfortunately, my other youth workers, they've got different skills, but music is not one of their skills. And in that studio, it needed somebody who knows how the equipment works, how the system works. (Centre Manager)

During our fieldwork in 2015-16, Shipman youth centre was the only one of Newham's four youth centres to have a dedicated music space/recording studio in use. ${ }^{2}$ However, on all but two of a dozen visits the studio was locked as the centre did not have the staff to run it. The

\footnotetext{
${ }^{2}$ The studio has a recording booth, a handful of Apple computers, chairs and a sofa.
} 
combination of a loss of skilled youth workers along with a substantial reduction in the number of sessions provided within Newham's youth centres, has had a chilling effect on the rap culture in Shipman and Forest Gate Youth Zones. Budget cuts are not the only pressures to which London's rap cultures are subject. The policing of nightclubs has also had a notable effect on restricting performances by the city's grime artists (Ilan 2012). However, it is important to highlight how policies developed by both national and local government have an impact on urban youths' participation in this rap culture, through providing or reducing access to space, equipment, staff support, and technical knowledge.

It is clear that state-funded institutions - and youth centres in particular - can play an important role in nurturing rap scenes. Forest Gate Youth Zone is but one example of youth centres facilitating the meeting of young people interested in rap, thereby acting as a training ground in which youths are able to develop their creative practice. In many cases, youth centres provide free access to music technology, something that young people can rarely find elsewhere. While one can rap without technology, technology is central to much of contemporary hip-hop and grime culture, whether in the form of rapping live into a microphone or recording and producing a track. Furthermore, music production requires significant skills and expertise. Although some young rappers are self-taught our research has shown that youth centre staff are important sources of guidance. However, while youth centres can provide access to space, technology and the social support to become involved in rap culture, young people will usually be expected to conform to certain 'house rules', which as we show below, shapes rap practice.

\section{Docklands youth centre, St Pauls, Bristol}

St Paul's is an inner-city area of Bristol in South West England, which from the mid-twentieth century became a home for migrants from Jamaica and other Caribbean islands. It has 
historically been one of Bristol's poorest neighbourhoods, and parts of St Paul's have been seen as areas in which crime flourishes (Pryce 1979). During the first half of 2016, we spent six months visiting St Paul's once, and sometimes twice, a week. Our primary field site was Docklands Youth Centre. The building was originally established in the 1920s as part of a national network of Dockland Settlements, which aimed to provide refuge and support to young people in deprived areas. In various guises it has been a hub for the community and young people, including as a home for music making.

Like youth centres in Newham and many other parts of England, Docklands has had to face the consequences of substantial cuts to youth service budgets. In 2015, as part of a Community Asset Transfer, the Docklands building was transferred by the Council to two local youth organisations, Full Circle and ACE (Aspiration, Creation, Elevation), for a fifteen-year period. As part of the contract the Council leased the youth centre building, but Full Circle and ACE became responsible for fundraising for the operational costs of the youth centre (Bristol City Council 2010). Full Circle, which was led by Delroy Hibbert until 2016, has a relatively broad offering, co-ordinating sports, games, girls only groups and other activities, five days per week. ACE provide sessions in the music studio two nights per week for local young people: on Tuesdays for under-elevens and Wednesdays for eleven to sixteen-year olds. There are also a handful of young people between sixteen and eighteen who ostensibly attend the Wednesday sessions as volunteers but come primarily to socialise with other young people and make use of the centre's music facilities. ACE is a three-person team, made up of Darren Lynch Burton, Cherelle Grant and Hans Soghe, who are all in their late twenties and early thirties.

Docklands youth centre has three principal spaces: the main room (with TV, PlayStation and seating area, a pool table, and a large table for group work), the sports hall (for football and basketball) and the music studio. On Wednesday evenings there are usually between ten and thirty young people who pass through the music studio. ACE's primary work 
involves running music performance and recording sessions in the music studio. The vast majority of the music created is rap. While rap is performed and recorded in a range of private and public spaces across the city, Docklands is a key node in the Bristol rap scene. It provides a space for young people to come together, perform, record and spectate in relatively large numbers and with free access to high quality music and computer technology. The music studio is divided into the 'live room' and the recording space, henceforth referred to as the studio.

\section{The live room and the studio}

The live room and the studio at the Docklands Youth Centre carry different ethical, aesthetic and social expectations. In the live room - which is equipped with decks, a laptop, an electronic drum kit, PA speakers and a microphone - young people are largely left to their own devices to listen and dance to recorded music and to rap over instrumental tracks. Performances in this space range from a sole teenager practicing their 'bars' (rap lyrics) to twenty young people involved in a rap battle, whether as rappers or spectators. There is also a degree of gender selfsegregation. While girls do use the live room they rarely rap. Occasionally they participate as spectators during freestyle sessions. More often girls use this space to chat, watch music videos, and dance to music in female only groups. For much of the Wednesday evening sessions, the room is used mainly by boys. Although the different way that girls used the space may have been influenced by the availability of girls only activities in the main room, staff occasionally encouraged girls to write and perform rap. Despite this, girls were infrequent performers of rap within the youth centre.

The live room is accessed from the central area by a sound-resistant door with a cut out window that allows people to see through between the two spaces. However, staff rarely enter the live room and there is a mutual acknowledgement that it is a space owned principally by 
the young people. When staff do enter, this is primarily to dissuade attendees from using offensive language or aggressive behaviour. As ACE-member Cherelle explains:

We always say we want it supervised, but for some reason it just never gets supervised, and it's just become a thing now.... we built that relationship with the young people, so we hope that they're sensible enough when they're in there they know to look after the equipment, and just behave. Do you know what I mean? And it runs quite nicely, to be honest, it's just their own little thing and they start it, they end it when they want ... and they form their own little community whilst they're in there.

For most of the night the live room is the boys' and girls' territory. It is space that appears to be understood by young people and staff alike as relatively free, playful and experimental. Much of the rap performed by the boys the live room takes the form of dissing, which frequently contains explicit or offensive language that would likely be challenged by the staff beyond the limits of the live room.

Following my [author-one] entrance into the live room while young people rap Hans playfully knocks on the window, telling the boys to 'pour fire on him'. This initiation into the space signals to the boys that they should continue to act in their usual manner and provides the opportunity for my presence to be acknowledged but made unexceptional. I am spared being made subject to any lyrics, and the boys direct their raps to one another. One boy after another takes the microphone and addresses his raps to another, usually the person that had passed him the mic. The boys boast about their own accomplishments and deride their opponents' features, family members, or claim some form of sexual relation with their antagonist's mother. At one point a boy calls out 'everyone fire on everyone'. As the microphone changes hands, the lyrics are directed towards any member of the assembled group. Despite the frequent use 
of the word 'nigga' and the consistent dissing, throughout this session there is an orderliness to the exchange between the rappers and audience members. On one occasion a rapper, about to pass the mic to one of two boys who both had their hands up, is told by another rapper that only one of the boys had said 'please' so he should get the mic. Most of the lyrics are crude, often stock jokes or rhymes, but occasionally the group bursts out in laughter in response to an exceptionally funny rap. This is a place where young, relatively inexperienced rappers come to spend time together and begin to craft their art.

The live room provides the opportunity for these boys to informally socialise, relatively free from adult oversight. In this space the boys draw on the tradition of playing the dozens (Abrahams 1993; Brown 1972). The overwhelming mediocrity of the lyrics performed in this space highlights the relatively undeveloped lyrical abilities of the participants. The immediacy of the feedback from their peers provides an important mechanism through which these young rappers hone their skills and develop their confidence in performing in front of an audience. While the spontaneity of performance and the immediacy of feedback are perhaps the most striking and enjoyable features of the rapping in the live room, there is a marked difference in the quality of the lyrics performed in that space to those performed in the recording booths. By contrast, the atmosphere in the studio tends to be more focussed. ACE staff work closely with young people, often one-to-one, recording their rap songs and offering guidance on music production. Those who hang out in the live room tend to be younger. Although there is some back and forth between the two spaces the older, more experienced, rappers prefer to use the studio. Lyrics performed in the studio are usually read (either from paper or, more often, mobile phones) indicating a stronger sense of creating a 'work' than is evident in the participatory and improvisatory environment of the live room. 
The studio, in contrast to the live room, has a more serious, 'professional' ethos, involving greater interaction between young people and staff. Although girls are often present in the studio they rarely make use of the recording booths. There is also a strong distinction between the sociality of performance in the live room and the recording of individual rap performances that takes place in the recording booths. Furthermore, while performance in the live room is ephemeral, the act of recording performance in the studio is understood by the staff and young people to be more tangible and concrete. This is perhaps one reason why staff in the studio are more eager to challenge young people's use of offensive language and depictions of criminality. Cherelle, for example, described a recording session in which a boy began to rap about drug dealing and using a knife, while using offensive language. She managed the situation by allowing the young person to continue to record his lyrics up until the end of the track, then explained that while it was his choice to rap in this way, it was not acceptable, and he would not be allowed to take a copy of the recording away from the youth centre. This is an important example of how staff try to balance the aim of allowing young people to express themselves against the construction of moral values through rap. It also highlights how Docklands plays a role in limiting and mediating the circulation of rap. Most youths at Docklands do not otherwise have free access to professional recording equipment, consequently the circulation of their songs is somewhat contingent upon conforming to staff expectations. While it was not uncommon to hear raps in the live room performed through the persona of a drug-dealer, these rarely made it into the studio. This self-censorship usually went uncommented upon but sometimes became a subject of discussion. On one occasion one of the youngest attendees, was listening back to a cover he had recorded of a recent commercial rap. As he listened with Cherelle he exclaimed 'did I just say something about selling crack?', before saying 'aww man, I'm going to have to re-spit those bars'. On a few other occasions [author-two] observed from afar young people censoring each other for similar kinds of things 
when staff were not involved. The internalisation of staff's views of acceptability highlights how the institutional ethos shapes rap practice.

\section{Docklands youth centre and the local rap scene}

Docklands contributes to the Bristol rap scene in several important ways. The youth centre introduces young people to rap, enables aspiring rappers to meet others with shared interests, and provides opportunities to perform, record and disseminate their songs. For some young people, Docklands may be the first place they rap in front of an audience. For many young rappers, the youth centre is where they encounter professional music technology for the first time. By providing the social context as well as the technological equipment and staff expertise, Docklands offers young rappers in and around St Paul's the chance to develop their skills as performers and recording musicians. The contrasting orientations, between the live room's informal collective performances and the more formally organised recording of individual rappers in the studio, provides a structure through which young rappers can develop. Docklands youth centre also helps to create social and creative networks of young people, even facilitating the formation of rap groups. One such crew, Oosoo Wavey, is made up of four young male rappers aged between fifteen and eighteen. The group was formed in 2015 after the four members, who met one another in the youth centre decided - with the encouragement of ACE staff - to join together under the banner of a single name. The members of the crew have performed together at events in Bristol, recorded several tracks posted online, and achieved recognition by other rap crews in the Bristol rap scene.

Docklands youth centre is also a site that facilitates young people's connections with the wider rap scene in Bristol. One of the ways in which this is evident is through the regular presence of Simz; full name, Simeon McCarthy. Simz is a well-known figure in the Bristol grime scene. In addition to working as a tiler by day he is one of Bristol's go-to music video 
producers for the city's emerging rap performers. He has his own YouTube channel, Simz City TV, where he has uploaded nearly 400 music videos, which in total have attracted nearly three million views and over 6,000 subscribers. This cultural entrepreneur is one of the key links between Docklands and Bristol's urban music economy. He regularly attends the Wednesdayevening sessions at the youth centre, often coming straight from work wearing his splattered overalls. While he has no formal relationship with the centre and is not involved in directing any sessions he has long-standing relationships with the members of ACE and has been involved in producing music videos with a number of young adults from Docklands.

During our fieldwork we observed the recording of a track called 'Shook', a collaboration between Stripzz and Murkzy. While Stripzz was a Docklands regular, Murkzy only began attending the youth centre after the pair discussed working on a 'colab' together through Facebook. When Stripzz and Murkzy came down to Docklands one Wednesday to record the track they had worked on their lyrics in advance. Their song boasted about their rapping abilities (e.g. 'Man go hard when I spit, you Gs know that I'm sick'), stressed a hardworking ethic (e.g. 'I'm here for the grind, no question') and highlighted their determination and resilience in the light of criticism from 'haters' (e.g. 'How can they try and hate on a man trying to make it' and 'I don't care who you are, don't care where you're from, go and let another man go and think I'm shook'). There is a significant contrast between the hard working ethic represented in 'Shook' and the ethos conjured through references to criminality in the song Cherelle refers to above. Within the space of a month of the audio track being recorded at Docklands, a music video for 'Shook' had been recorded and produced by Simz and published on his channel. While Simz often records music videos 'on location' in and around Bristol he sometimes also uses the youth centre to record footage of performers recording in the studio. During our fieldwork, Simz often turned up midway through a session: 
During a Wednesday-evening session Cherelle begins to record [a boy] who is rapping in the booth. Despite being twelve and relatively inexperienced he has a decent flow and a relaxed confidence about him. He has a deep voice for his age. Simz arrives and is seemingly impressed saying 'this guy thinks he's a $G$ '. After [the boy] comes out of the booth, Simz begins asking him about how long he'd been rapping and if he was around at the weekend to record a video. Cherelle and Hans are noticeably uneasy about Simz's invitation. Hans challenges Simz, asking 'What are you doing to the youth?' 'You've got to let them grow, to develop'. Simz explains he wouldn't record it himself and that it would be a good opportunity for his cousin to practice filming. Hans replied 'make sure you don't put it [the video] out ... we don't want them to get carried away'.

This vignette indicates some of the ways in which Docklands is enmeshed in the Bristol rap scene and raises important questions about the relationship between local rap culture and the youth centre as an institution. Docklands contributes substantially to the scene through the formation of young Bristol-based rappers and the production of local rap performances and recordings. It also facilitates young people's access to the wider scene through relationships with key gatekeepers such as Simz. However, friction can occur between the ethos of the youth centre and ACE, on the one hand, and external entrepreneurial figures such as Simz, on the other. Simz represents the worlds of private enterprise and the cultural industries. Among the youth workers there is a sensitivity around nurturing and mentoring children and young adults without pushing them towards the urban music economy too early or to their detriment. This is, in large part, driven by a greater emphasis on developing young people as ethical citizens than on developing their creative capabilities. This situation raises important questions about the role that rap plays in young people's social practices and youth workers' use of this cultural 
form as part of their professional practice. Before turning to these questions, we examine why it is important to explore issues such as these through an institutional lens.

\section{The institutions come first: towards an institutionalist approach in rap culture studies}

In our account of contemporary grime culture, we have highlighted the role that youth centres play in shaping the practices of aspiring rappers. These institutions bring together young people with an interest in rapping, provide opportunities for collaborative performance and recording, and facilitate (or restrict) the distribution of the cultural products produced within them. In addition to drawing attention to the importance of youth centres to grime culture specifically, we argue that an understanding of the role of institutions is necessary for the analysis of rap cultures more broadly. We want to build on work by scholars such as Negus, Forman, and White, to emphasise the centrality of social and cultural institutions to the development of rap. An institutionalist approach to the historical development of US rap culture could highlight, for example, the significance of affordable housing to the formation of hip-hop. Discussions of early hip-hop often refer to DJ Kool Herc (Chang; Rose; Forman). Herc, who migrated with his family from Jamaica to the US, played an important role in the adaptation of soundsystem culture and the development of hip-hop. We suggest that the provision of affordable housing and the availability of an association room in 1520 Sedgwick Avenue, suitable for Herc and his sister to use for their parties, was an important factor in the earliest stages of what came to be known as hip-hop culture. The subsequent movement of the artistic, cultural, and entrepreneurial practices employed by Herc, from the space provided through an affordable housing programme to the commercial contexts of the nightclub and, later, the recording industries, highlight the different kinds of opportunities and limitations provided by these distinct institutional contexts. 
White's analysis of the urban music economy highlights how young people develop their identities through entrepreneurial activities. Although she does not employ the concept of the institution, her focus on entrepreneurial activities within the framework of the urban music economy allows her to demonstrate how this 'social field' (White 2017) is developed through pirate radio, internet radio, online broadcasting, and music video production. We suggest that this field is also shaped by the activities of institutions that are wholly or partly funded by local or national government, such as Forest Gate Youth Zone and Docklands. Furthermore, by bringing the role of institutions into the centre of rap studies, it is possible to produce a more complete account of key moments of creativity, innovation, and growth in these cultural fields. Murray Forman's discussion of space and place in hip-hop and rap, highlights the importance of spatiality in the analysis of this cultural field. We want to build on his approach, which, by moving beyond a focus on authenticity and identity that has dominated debates within hip-hop studies, is capable of highlighting the mythic status of 'the street' in accounts of this culture.

Forman builds on Keith Negus's analysis of the recording industry, to examine the influential role that institutional processes played in rap culture from the mid-1980s. However, his emphasis on space and place during the early years of hip-hop's development has a significant limitation; reducing the role of key institutions to a background context for cultural developments that are then seen to be driven primarily by rappers and djs. For example, although Forman's analysis of the significance of 'The Message' emphasises that this song was a 'departure from most other successful commercial rap releases up to that point', his focus on space and place in relation to this recording limits his concerns with spatiality to the song's themes: 'With "The Message," rap's discursive focus extended the genre's thematic boundaries, which up to this point had mostly been isolated in the conceptual loci of the party, nightclub, or roller rink' (Forman 2002). We argue that the focus on MCs, DJs and songs within hip-hop studies obscures the important role played by other actors and organisations. It is 
significant that this song (which Forman acknowledges had a substantial impact on later rap recordings) was produced within the organisational context of a recording company. Forman celebrates Grandmaster Flash and the Furious Five, attributing the song's significance and innovativeness to their artistry: 'Rising rapidly as one of the most prominent groups of the New York rap scene, Flash and his crew were able to articulate transitions in style and musical content by combining their ample skills and innovative abilities with a particular youthinflected social perspective.' (Forman 2002). In contrast to Forman, we suggest that an institutional approach to the historical development of hip-hop culture offers the opportunity to provide a more nuanced account of the song's production and cultural significance.

Drawing on Grandmaster Flash's autobiography, ${ }^{3}$ Kajikawa's account of the making of 'The Message' highlights the significance of the recording company and its commercial interest.

Early in 1981, Sylvia Robinson approached Grandmaster Flash with a tape of something Ed Fletcher, the percussionist in Sugar Hill's house band, had written. Robinson was convinced that the recording held the key to Sugar Hill's next big hit, and she insisted that the group adopt the song and record it as soon as possible. Having recently made the transition from live club group to recording artists, Flash and his group remained skeptical. He remembers that nobody liked it. "The shit was way too dark, way too edgy, and way too much of a downer. It was the furthest thing from a party rap anyone could imagine." Flash remembers doing his best to forget about the tape. Not one to be deterred, Robinson hounded the group for almost a year until she convinced MC Melle Mel to begin recording the track without Flash's consent. (Kajikawa 2015)

\footnotetext{
${ }^{3}$ Grandmaster Flash, The Adventures of Grandmaster Flash: My Life, My Beats (New York: Random House, 2008) p. 157
} 
It is important to highlight not only that the interests of this commercial organisation were at variance with some of the members of the group, but that this institution required and brought together different actors: including Sylvia Robinson; members of the house band; and the members of the group, Grandmaster Flash and the Furious Five. As a result of this coming together of different people, perspectives, and interests, the practices of MC Melle Mel (and many rappers following the release of this song) moved away from dance oriented disco raps towards a more narrative style (Kajikawa 2015). Furthermore, an important aspect of the song's significance is that it is a product of the restructuring in relations between MCs and DJs, with Melle Mel being brought to the fore as Flash is marginalised. This is a result of processes within the music recording industry, that are better described as institutional (or organisational) rather than spatial. We want to build on White and Negus, as well as Forman's later analysis of the development of hip-hop, to highlight the need for greater critical scrutiny of the role of institutions in shaping rap cultures. Our attempt to develop an institutionalist approach to the study of rap culture at Docklands gives greater recognition to a wider range of social actors, who help rappers to develop their skills and craft their work, as well as the social forces that come to bear upon the production, performance and dissemination of rap recordings.

\section{Cultivating affective subjects and ethical citizens through rap}

Despite the substantial body of work on rap music in the recording and wider cultural industries (Negus; Forman; White; Kajikawa), the role of publicly funded and charitable organisations has received too little attention within studies of rap cultures. While some scholars have examined young people's participation in hip-hop culture within government funded or supported organisations, these institutions become rendered part of a background context with scant attention given to how they shape artistic and cultural practice. We argue that it is important to consider how the values, practices, and social orientations associated with rap are 
shaped within institutions. Furthermore, we are concerned with analysing the role that the state plays in shaping local rap cultures. The state's role operates not only through the provision or withdrawal of funding for organisations such as youth centres, but also through social policy objectives and how these are interpreted by those working with young rappers. We have examined how rap performances are facilitated within Docklands, how recordings are disseminated through figures such as Simz, and how youth workers restrict the dissemination of lyrics that they consider inappropriate. In this final section, we aim to highlight how these activities are primarily aimed at developing ethical citizens through rap culture.

The contrasting responses to 'Shook' and the song Cherelle describes above highlights one important way that this institution produces different outcomes for young people's creative practices. White's (2017) discussion of the grime scene in Newham identifies how music videos used by grime MCs to promote their work have become subject to 'surveillance and intelligence gathering for the regulating authorities'. White examines how the criminalisation of young people's leisure activities involves a process in which a 'number of institutions, including local authorities, the metropolitan police and the judiciary, use the concept of "risk assessment" to pin down and organize the movements of urban music'. Dockland's youth centre leader, Delroy, highlights the role the centre can play in tackling anti-social behaviour, issues around accessing funding, and the contact that members of Docklands have with other organisations including the police, in his discussion of the reduction of youth services in Bristol.

We work in an area where if young people don't have things to do, they can get involved in antisocial behaviour, which can have serious consequences and costs for society. Now, I'll give you an example of this: I sat down with a couple of youth workers, a couple of police officers and a couple of gang members a couple of years ago, and we were talking about what would it take, what do they want from us to get them off the 
street? It was a really interesting conversation, and what it pretty much wanted was more time and access in the studio, and activities like learning, cooking skills and life skills; and also help finding apprenticeships. Now, following that conversation, I spent nearly two years running around trying to get funding to do - I mean, what they were describing was pretty much an anti-gang project - to get money for an anti-gang project. I never got hold of that money. One of those young people is now currently on remand for the murder of a young person. ... So I've got a phrase which I use, which is prevention is cheaper than cure. And it's a very short-sighted policy to reduce youth working, especially to organisations like ours, which are community-based, and which the kids are accessing. (Delroy, Full Circle)

Although Full Circle and ACE do not have a formal relationship with Bristol City Council's anti-gang initiatives, young people's internalisation of views regarding acceptable lyrics and the contrasting ways in which the circulation of rap lyrics recorded at Docklands is facilitated or restricted highlights how the aims of social and criminal justice policy are informally implemented in institutions outside the criminal justice system.

In her study of the development of the Department for Community and Local Government's (DCLG) community cohesion agenda, Anne-Marie Fortier (2010) highlights how strategies 'deployed in view of achieving cohesion operate through mechanisms of subjectivation -that is, through the cultivation of responsible, discerning, rational, autonomous subjects who bear full responsibility for their lives.' Fortier argues that governing strategies connected with this social policy agenda "address the "affective subject": that is, a subject whose conduct arises from desires, fears, anxieties, insecurities, affection, care, dis/trust, un/ease and so on' (ibid.). Youth workers explicitly draw on social policy discourse in their discussions of the value of their work: for example, 'social cohesion most definitely is one of 
our contributions to society' (Cherelle). Moreover, as we outline below, rap is a means through which they address young people as affective subjects as part of a focus on young people's ethical development. We argue that the use of rap to cultivate ethical citizens not only highlights the impact of rap on young people's identities in England, but has significant implications for how this art form is understood within this youth centre and beyond. This ethical imperative has consequences for how rap is thought about within these organisations and, consequently, on the rap cultures produced through them. Fortier (2010) cautions against assuming the "“success" of governmental projects in achieving the desired aims or in how they are translated into practice "on the ground"'. Cherelle's identification of how Docklands contributes to social cohesion, refers to the bringing together of young people who develop shared interests. However, as most of the rappers in the studio are young black males, this type of interaction might be considered a bonding activity, rather than the sort of bridging activity favoured by the DCLG (Fortier 2010). Social policy is interpreted, misinterpreted, and adapted in a variety of ways by practitioners. Nevertheless, social policy discourse frame debates and influence practices. We argue that this has implications for how rap cultures in England are fostered within and beyond social organisations. The links that Docklands has with the urban music economy on the one hand and with criminal justice agencies on the other, results in concerns about social cohesion, anti-social behaviour, and participation in the urban music economy coming to the forefront of considerations about rap, while other factors receive less overt consideration.

Members of ACE are motivated by the aim of achieving social justice by cultivating young people's sense of responsibility for their own conduct. As part of this approach youths are addressed as affective subjects and rap is principally used as an 'engagement tool'.

The music is the engagement tool, first and foremost, so they come because they want to use the studio, or they want to learn new skills and that's what we do. Come 
along, and that's how we build the relationship as well, teaching them ... And that's where the ethical stuff comes in, and that's where it comes to teaching and trying to help these young people to really think about their choices, and the decisions that they make. (Cherelle)

This emphasis placed by the youth workers on the music's instrumental value to a pedagogy of ethics, contrasts with the artistic value given to rap music by some of the young people at Docklands:

Kendrick Lamar is my favourite rapper, like the way he articulates like he's a poet. He is a poet. The way his music is, like it makes me feel it, like the jazz, the instruments that he'll play, and the way that he'll perform. It's like a piece of art. But it's- and a piece of art- it makes you think. (Devonte)

Youth workers clearly have views about aesthetic value. For example, when we asked what skills make for a good rapper, Cherelle emphasised timing and the relation between the words and the beat in a rapper's performance: 'if you can't sit on that beat tight, that's the first thing I'll notice'. However, there are rarely discussions about the formal aspects of rap performance in the studio, and none of the feedback that we observed included references to lyrical structures, rhetorical devices, the use of persona and other generic conventions, or how young people might improve their timing or 'flow'.

Although ACE focus on developing young people as rational autonomous subjects, rap has an important role to play because of its influence on their emotional state as well as its potential value as a means for self-expression.

So when young people engage in music, they find themselves, what's the word?

Elated. So they find themselves actually free of some constraints, because they're doing something that's actually heightening their emotional and expressive self. ... It allows you to almost get like a running start when it comes to actually getting 
to know them, and getting them to understand and learn, and develop as people.

(Darren)

This may be considered as a two-pronged strategy through which ethical citizens are produced at Docklands. First, young people are addressed as 'affective subjects' through the aesthetic experience that they find through music. Second, their speech, conduct, and the way they feel about their relations with others are shaped through the facilitation of rap performance, discussion about lyrical content, opportunities to record and disseminate rap songs, and restricting the circulation of recordings that are considered unsuitable. Our research at Docklands points toward rap music and its affective potential being used as a governing strategy for the development of young ethical citizens.

\section{Conclusion}

In this article we have made the case for hip-hop studies to move beyond tropes of 'the street' and a focus on the expression of social identity to pay greater critical attention to the role of institutions in rap cultures. While our arguments can be extended and adapted to understand the role of a range of private and public institutions our focus here has been on youth centres in London and Bristol that are wholly or partially supported by local government. We have shown how youth centres make significant contributions to rap culture. Forest Gate Youth Zone in Newham, was once at the heart of London's emergent grime scene and served as a site in which young people could hone their creative skills. Docklands youth centre in St. Paul's, continues to make an important contribution to the Bristol rap scene as well as the ethical development of young people in the local neighbourhood. Youth centres can facilitate rap culture in a variety of ways, including through the provision of space, technological resources, staff expertise, and the freedom to play. 
In addition to making a distinctive contribution to mainstream popular culture, rap's role within institutions highlights that this cultural form is in dialogue with mainstream political agendas. Much work has considered how the state suppresses or marginalises rap culture. However, national and local governments also facilitate, shape, and instrumentalise rap, through social policy, funding streams, and local organisations. Institutional structures, practices and discourses shape how rap is valued and thought about. Within Docklands critical thinking about rap's aesthetic qualities or guidance regarding the development of lyric writing is subordinated to rap's utility in teaching ethical values. Furthermore, this organisation plays a role in producing young people as affective citizens, who bear responsibility for their lives, through their participation rap culture. The caution that youth workers exercise about young people's engagement in entrepreneurial activity, the emphasis they place on ethical development and social conduct, and the relative lack of concern about the aesthetic qualities of rap, are important aspects of how rap culture is incorporated into the processes of this institution. Finally, the performance and dissemination of rap, the conversations around music and ethical values, and the links that are made between young people within and beyond Docklands, highlights the significance of role that this institution plays in this field of cultural production. 


\section{Bibliography}

Abrahams, R. 1993. 'Playing the Dozens', in Alan Dundes (ed.) Mother Wit From The Laughing Barrel (Jackson, University Press of Mississippi)

Alasuutari, P. (2015) ‘The Discursive Side of New Institutionalism’ Cultural Sociology Vol. 9(2) $162-184$

Anderson-Butcher, D., Cash, S., Saltzburg S., Midle, T., and Pace, D. (2004) Institutions of Youth Development, Journal of Human Behavior in the Social Environment, 9:1-2, 83-99

Baker, G. 2005. ‘¡Hip Hop, Revolución! Nationalizing Rap in Cuba’ Ethnomusicology Vol 49, No. 3, pp. 368-402

Baker, G. 2011. Buena Vista in the Club: Rap, Reggaetón, and Revolution in Havana (Durham NC, Duke University Press)

Banks, M. (2007). The Politics of Cultural Work. Basingstoke; New York: Palgrave Macmillan Bennett, A. 1999. 'Rappin' on the Tyne: White Hip Hop Culture in Northeast England' The Sociological Review, 47/1, pp. 1-24

Bradley, A. 2009. Book of Rhymes: The Poetics of Hip-Hop (New York: Basic Civitas)

Bramwell, R. 2015. UK Hip-Hop, Grime and the City: The Aesthetics and Ethics of London's Rap Scenes (New York and London, Routledge)

Bristol City Council 2010 ‘Community Asset Transfer Policy’ https://www.bristol.gov.uk/documents/20182/35144/Community\%20Asset $\% 20$ Transfer $\% 20$ Policy.pdf/69a22e3e-7ab8-42fc-9de2-8b26f2e7d9ea

Brown, H. 1972. 'Street Talk', in Thomas Kochman (ed.) Rappin' and Stylin' Out (Urbana; London: University of Illinois Press) 
Cermak, M. J. 2012. 'Hip-hop, social justice, and environmental education: Toward a critical ecological literacy', The Journal of Environmental Education, 43/3, pp. 192-203

Chang, J. 2007. Can't Stop Won't Stop: A History of the Hip Hop Generation (New York: Ebury Press)

Clay, A. The Hip-Hop Generation Fights Back; Youth, Activism and Post-Civil Rights Politics New York University Press

Dimitriadis, G. 2009. Performing Identity/performing Culture: Hip Hop as Text, Pedagogy, and Lived Practice (New York: Peter Lang Publishing)

Elligan, D. 2000. 'Rap therapy: A culturally sensitive approach to psychotherapy with young African American men', Journal of African American Studies, 5/3, pp. 27-36

Emdin, D. (2010) 'Affiliation and alienation: Hip-hop, rap, and urban science education' Journal of Curriculum Studies 42 (1), 1-25

Fortier, Anne-Marie (2010) Proximity by design? Affective citizenship and the management of unease, Citizenship Studies, 14:1, 17-30

Forman, M. 2000. “"Represent”: Race, Space and Place in Rap Music', Popular Music, 19/1, pp. $65-90$

Forman 2002. The 'Hood Comes First: Race, Space, and Place in Rap and Hip Hop Middletown, Connecticut: Wesleyan University Press

Hall, P and Taylor, R (1996) 'Political Science and the Three New Institutionalisms' Political Studies XLIV, 936-957

Hallman, H. L. 2009. “"Dear Tupac, you speak to me”: Recruiting Hip Hop as Curriculum at a School for Pregnant and Parenting Teens', Equity \& Excellence in Education, 42/1, pp. 36-51 Hoyler, M. and C. Mager. 2005. 'HipHop ist im Haus: Cultural Policy, Community Centres, 
and the Making of Hip-Hop Music in Germany', Built Environment 31/3, pp. 237-254

Ilan, J. 2012. "The Industry's the New Road": Crime, commodification and street cultural tropes in UK urban music', Crime, Media, Culture, 8/1, pp. 39-55

Kajikawa, L. 2015. Sounding Race in Rap Songs (Oakland: University of California Press)

Keyes, C. 2004. Rap Music and Street Consciousness (Urbana and Chicago: University of Illinois Press)

Krims, A. 2000. Rap Music and the Poetics of Identity (Cambridge University Press)

Kuttner, P. J. 2015. 'Educating for cultural citizenship: Reframing the goals of arts education', Curriculum Inquiry 45/1, pp. 69-92

Morrell, E. and J. M. R. Duncan-Andrade. 2002. 'Promoting academic literacy with urban youth through engaging hip-hop culture', English Journal, pp. 88-92

Negus, K. 1999. 'The Music Business and Rap: Between the street and the executive suite', Cultural Studies, 13/3, pp. 488-508

Olson-McBride, L. and T. F. Page. 2012. 'Song to self: Promoting a therapeutic dialogue with high-risk youths through poetry and popular music', Social Work with Groups, 35/2, pp. 124137

Pardue, D. 2004 “"Writing in the Margins": Brazilian Hip-Hop as an Educational Project', Anthropology and Education Quarterly, 35/ 4, pp. 411-432

Pryce, K. 1979. Endless Pressure (Harmondsworth: Penguin)

Regev, M 'Ethno-National Pop-Rock Music: Aesthetic Cosmopolitanism Made from Within' Cultural Sociology 1(3): 317-341

Rose, T. 1994. Black Noise (Middletown, Connecticut: Weslyan University Press) 
Stephens, T., R. L. Braithwaite and S. E. Taylor. 1998. 'Model for using hip-hop music for small group HIV/AIDS prevention counseling with African American adolescents and young adults', Patient Education and Counseling, 35, pp. 127-37

Tillie Allen, N. M. 2005. 'Exploring hip-hop therapy with high-risk youth', Praxis 5, pp. 3036.

Turner, P. 2017. Hip Hop Versus Rap London and New York: Routledge

Urpelainen, J. 2011. 'The origins of social institutions' Journal of Theoretical Politics 23(2) $215-240$

White, J. 2017. 'Controlling the Flow: How Urban Music Videos Allow Creative Scope and Permit Social Restriction' Young

White 2017b Urban Music and Entrepreneurship: Beats, Rhymes and Young People's Enterprise London and New York: Routledge 